\title{
Cytotoxicity of orthodontic materials - The search for the perfect orthodontic material
}

\author{
Matheus Melo Pithon ${ }^{1}$
}

For several years, experimental studies in Orthodontics have attempted to define the mechanical properties of various components of orthodontic appliances to improve bracket ${ }^{1}$ and orthodontic cement ${ }^{2}$ shear bond strength, reduce friction of wires and brackets, ${ }^{3}$ increase force of elastics ${ }^{4}$ and achieve several other improvements. ${ }^{5,6,7}$ However, adverse reactions of the oral soft tissues have raised the interest of researchers in determining the biological effects of these materials, that is, their biocompatibility (Fig 1).

Biocompatibility may be defined as the capacity of a material to perform its specific functions when applied to living tissues of certain hosts without causing any damage or harm. ${ }^{8}$ Orthodontic brackets, for example, should remain in the patient's oral cavity for a mean of 36 months, in close contact with the mucosa, but should not cause any irritation.

As the control of the use of laboratory animals has grown stricter, in vitro tests had to be developed and standardized to detect the possible toxicity of the devices to be used in human beings, particularly those for clinical applications, such as biomaterials, which should not expose the patient's organism to any adverse reactions or injury.

\footnotetext{
${ }^{1}$ Professor, Orthodontics, Universidade Estadual do Sudoeste da Bahia, Itapetinga, Brazil. MSc and PhD, Orthodontics, Universidade Federal do Rio de Janeiro, Brazil. Diplomate of the Brazilian Board of Orthodontics and Dentofacial Orthopaedics. Associate Editor, Dental Press Journal of Orthodontics.
}

Contact address: Matheus Melo Pithon Av. Otávio Santos, 395, sala 705 - Centro Odontomédico Dr. Altamirando da Costa Lima CEP: 45020-750 - Vitória da Conquista/BA - Brazil

E-mail: matheuspithon@gmail.com
According to the International Standard Organization (ISO 10993), in vitro cytotoxicity trials should be the first tests to evaluate the biocompatibility of any material to be included in biomedical devices. Only after confirmation of their non-toxicity should the investigation of the product's biocompatibility go on, with the necessary trials using laboratory animals. ${ }^{10}$

Several in vitro methods are available to test the toxicity of biomaterials. ${ }^{11,12}$ Most tests place the material directly or indirectly in contact with a mammalian cell culture, after which cell changes are evaluated using different techniques, such as the incorporation of vital dyes or the inhibition of cell colony formation..$^{13}$ The most common parameter to evaluate toxicity is cell viability, which may be demonstrated using vital dyes, such as neutral red. ${ }^{12}$ Several substances damage cell membranes and decrease neutral red uptake and bonding. Therefore, live cells can be distinguished from damaged or dead cells by measuring the intensity of the cell culture staining using spectrometry. ${ }^{12}$

In vitro methods have advantages over in vivo tests, such as the greater control of experimental variables, easier access to significant data and, in many cases, shorter test times. ${ }^{12}$

\footnotetext{
How to cite this article: Pithon MM. Cytotoxicity of orthodontic materials - The search for the perfect orthodontic material. Dental Press J Orthod. 2012 JulyAug;17(4):2-3.

Submitted: february 02, 2012 - Revised and accepted: march 20, 2012

" The author reports no commercial, proprietary or financial interest in the products or companies described in this article.

" Patients displayed in this article previously approved the use of their facial and intraoral photographs.
} 

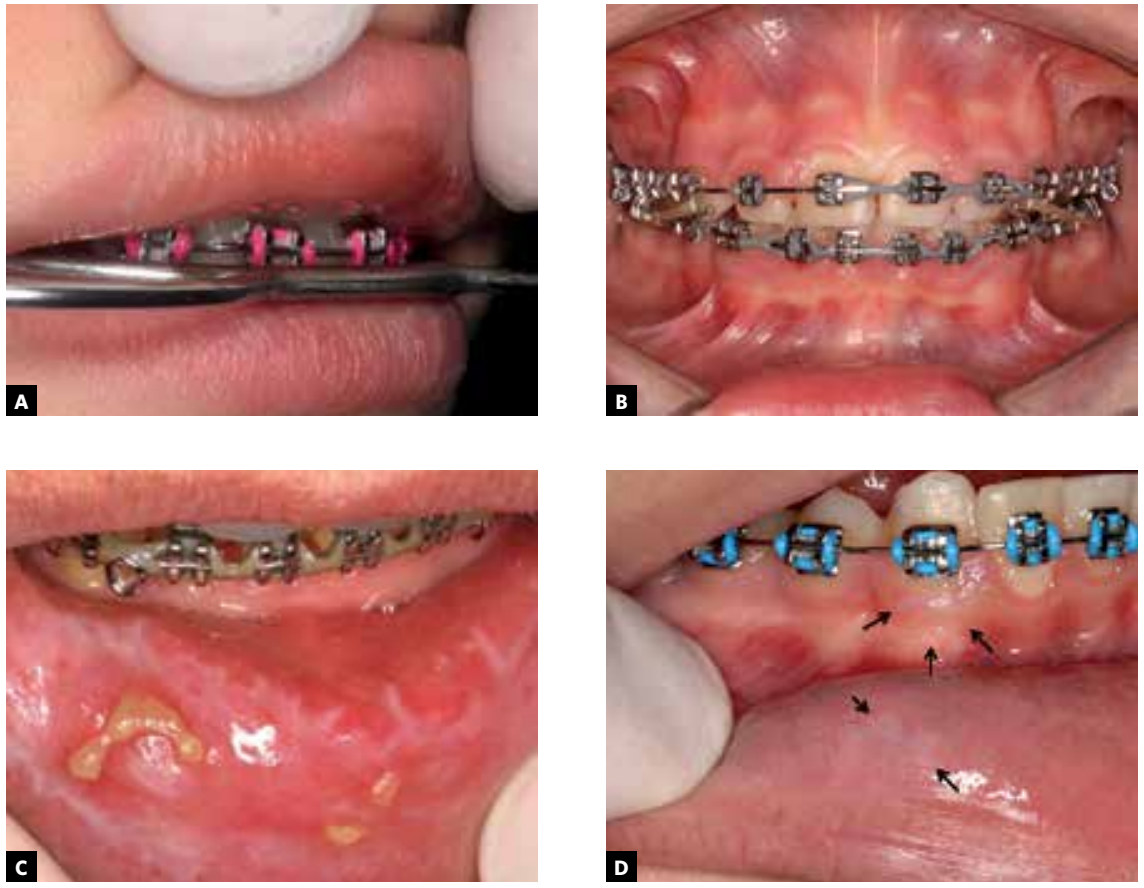

Figure 1 - A) Lip lesion due to contact with orthodontic solder of extraoral appliance. B) Inflammatory gingival reaction to contact with bracket bonding resin in patient with good oral hygiene. C) Lesion in mucosa after use of intermaxillary elastics. D) Lesion in gingiva and lower lip mucosa due to contact of self-conditioning agent in adhesive system.
Biological tests are important because a material to be used in the oral cavity should be atoxic and non-absorbable by the circulatory system and should not injure oral tissues. Non-biocompatible materials may be mutagenic or affect inflammation mediators, which may lead to systemic responses, such as toxic, teratogenic or carcinogenic effects. ${ }^{14}$ Such materials should be free of agents that may cause allergic responses in sensitive individuals.

The elucidation of how orthodontic materials behave when in contact with live tissues may bring answers to several clinical questions, such as: Why is the patient's gingiva hyperplastic even when oral hygiene is excellent? Is the pain assigned to the elastic bands caused only by their movement during use or also by their toxicity when in contact with the gingiva? Important to note that success in clinical orthodontics does not only depend on mastering corrective techniques to achieve ideal dental occlusion, but also demands the application of biosafety norms and the attention to the local and systemic consequences of the use of orthodontic materials.

\section{REFERENCES}

1. Pithon MM, Oliveira MV, Ruellas AC, Bolognese AM, Romano FL. Shear bond strength of orthodontic brackets to enamel under different surface treatment conditions. J Appl Oral Sci. 2007 Apr;15(2):127-30

2. Pithon MM, dos Santos RL, de Oliveira MV, Ruellas AC, Romano FL. Metallic brackets bonded with resin-reinforced glass ionomer cements under different enamel conditions. Angle Orthod. 2006 Jul;76(4):700-4.

3. Fidalgo TK, Pithon MM, Maciel JV, Bolognese AM. Friction between different wire bracket combinations in artificial saliva-an in vitro evaluation. J Appl Oral Sci. 2011 Jan-Feb;19(1):57-62.

4. Lacerda dos Santos R, Pithon MM, Romanos MT. The influence of pH levels on mechanical and biological properties of non-latex and latex elastics. Angle Orthod. 2011 Dec 9.

5. Pithon MM, dos Santos RL. Does ozone water affect the bond strengths of orthodontic brackets? Aust Orthod J. 2010 May;26(1):73-7.

6. Pithon MM, dos Santos RL, de Oliveira Ruellas AC, Nojima LI, Sant'Anna EF. In vitro evaluation of fluoride release of orthodontic bonding adhesives. Orthodontics (Chic.). 2011 Winter;12(4):290-5.

7. Pithon MM, Nojima MG, Nojima LI. Primary stability of orthodontic mini-implants inserted into maxilla and mandible of swine. Oral Surg Oral Med Oral Pathol Oral Radiol Endod. 2012 Jan 2.

8. Santos RL, Pithon MM, Fernandes AB, Cabral MG, Ruellas AC. Biocompatibility of orthodontic adhesives in rat subcutaneous tissue. J Appl Oral Sci. 2010 SepOct;18(5):503-8.

9. Rogero SO, Lugão $A B$, Ikeda TI, Cruz AS. Teste in vitro de citotoxicidade: estudo comparativo entre duas metodologias. Mater Res. 2003;6(3):317-20.

10. International Organization for Standardization. International standard ISO 10993-5, Biological evaluation of medical devices. 1992. Part 5: Tests for cytotoxicity: in vitro methods. Geneva (SH): 1992

11. dos Santos RL, Pithon MM, Martins FO, Romanos MT, de Oliveira Ruellas AC. Evaluation of the cytotoxicity of latex and non-latex orthodontic separating elastics. Orthod Craniofac Res. 2010 Feb;13(1):28-33.

12. Pithon MM, Santos RL, Ruellas ACO, Fidalgo TK, Romanos MTV, Mendes GS. Citotoxicidade in vitro de elásticos ortodônticos: comparação entre duas metodologias. Rev Saúde Com. 2008;4(1):19-26

13. Rogero SO, Souzabazzi A, Ikeda TI, Cruz AS, Fernandes KC, Higa OZ. Citotoxicidade in vitro das membranas de hidrogel reticuladas por radiação ionizante. Rev Inst Adolfo Lutz. 2000;59(1/2):1-5.

14. Santos RL, Pithon MM, Silva Mendes G, Romanos MT, Ruellas ACO. Cytotoxicity of intermaxillary orthodontic elastics of different colors: an in vitro study. J Appl Oral Sci. 2009 Jul-Aug:17(4):326-9. 